\title{
ANALISIS PENGARUH FLUKTUASI KURS VALUTA ASING DAN KEBIJAKAN HARGA BAHAN BAKAR MINYAK DALAM PERIODE 2000-2008 TERHADAP KINERJA PT ASTRA INTERNASIONAL DI INDONESIA
}

\author{
Mohamad Heykal'; Theresa Febrona'; Hidayatullah ${ }^{3}$ \\ 1,2,3 Jurusan Akuntansi, Fakultas Ekonomi dan Bisnis, Bina Nusantara University \\ Jln. K.H. Syahdan No. 9, Kemanggisan, Palmerah, Jakarta Barat 11480
}

\begin{abstract}
The fourth quarter in 2008 is the peak of Global Monetary Crisis, which is the decreasing of liquidity in companies around the world. The crisis also affected towards fluctuation of world petroleum price. Automotive industry in Indonesia was also affected towards cost of foreign exchange fluctuation and petroleum price due to the crisis. PT Astra International, Tbk. is assumed to represent automotive industry in Indonesia. The research is done through literature research and financial and sales report analysis in 2000-2008. The performance reduction is directly connected by the decreasing of earnings, especially in motor vehicle and parts sale in those years and also the increasing of cost of production, due to the increasing of import fee and transportation cost. Foreign exchange fluctuation and petroleum price directly affects the work performance of PT Astra Internasional.
\end{abstract}

Keywords: fluctuation, foreign exchange, petroleum price, motor vehicle sale

\begin{abstract}
ABSTRAK
Kuartal keempat di tahun 2008 merupakan puncak dari Krisis Keuangan Global, yaitu turunnya likuiditas perusahaan-perusahaan di seluruh dunia. Krisis ini pun berpengaruh terhadap fluktuasi harga minyak dunia. Industri otomotif di tanah air sangat rentan terhadap perubahan di Fluktuasi kurs valuta asing serta harga bahan bakar minyak (BBM) yang terjadi akibat krisis ini. PT Astra Internasional Tbk dianggap dapat mewakili industri otomotif di Indonesia. Penelitian dilakukan dengan cara penelitian perpustakaan serta analisis laporan keuangan dan penjualan tahun 2000-2008. Penurunan kinerja tersebut secara langsung diakibatkan oleh: turunnya tingkat pendapatan, terutama di penjualan kendaraan bermotor dan suku cadangnya di tahun-tahun tersebut dan naiknya biaya pokok pendapatan, akibat naiknya biaya impor serta biaya pengiriman. Fluktuasi kurs valuta asing serta kebijakan harga bahan bakar minyak mempengaruhi kinerja PT Astra Internasional secara tidak langsung.
\end{abstract}

Kata kunci: fluktuasi, kurs valuta asing, harga bahan bakar minyal, penjualan kendaraan bermotor 


\section{PENDAHULUAN}

Kuartal keempat di tahun 2008 merupakan puncak dari Krisis Keuangan Global, yaitu turunnya likuiditas perusahaan-perusahaan di seluruh dunia. Menurut Crotty (2008), gejala krisis ini sudah mulai terlihat di tahun 2001 ketika Alan Green Span mengungkapkan kondisi ekonomi Amerika yang cenderung lesu, terutama di bidang perumahan, asuransi serta tingkat upah minimum yang terus menurun. Belum lagi kebutuhan belanja militer Amerika yang terus meningkat untuk membiayai perang terutama untuk invasi ke Afganistan di tahun 2001 serta ke Irak di tahun 2003 yang mengakibatkan anggaran belanja Amerika untuk militer membengkak sampai 45,7 \% dari total anggaran pertahanan. Untuk mendorong pertumbuhan ekonomi, pemerintah memberikan kredit perumahan lunak untuk mendorong masyarakat membeli properti. Sehingga di akhir 2005 sampai 2006 penjualan perumahan mencapai puncaknya. Penyebabnya adalah bank dan broker perumahan mengejar komisi sebesar-besarnya dengan memberikan kredit perumahan (mortgage loans), bahkan kepada mereka yang sesungguhnya tidak mampu, yang pada akhirnya membiayai kredit tersebut dengan pinjaman dari bank maupun lembaga keuangan lainnya. Namun, pada kenyataannya kredit tersebut tidak dapat terselesaikan dan menimbulkan kerugian baik kepada bank, maupun institusi keuangan yang menjadi investor. Hal ini berakibat pada hancurnya kondisi keuangan lembagalembaga keuangan besar seperti Fannie Mae, Freddie Mac, Lehman-brothers, Merrill Lynch, Goldman Sachs, Morgan Stanley maupun Washington Mutual di tahun 2008. Lembaga-lembaga ini memiliki kerja sama dengan lembaga-lembaga keuangan lain di luar Amerika sehingga kebankrutan mereka juga mempengaruhi lembaga-lembaga keuangan terkait dan kondisi keuangan negara bersangkutan. Hancurnya lembaga-lembaga keuangan besar di Amerika juga menyebabkan industri-industri di Amerika mengalami kesulitan dana sehingga menaikkan harga dan memperketat impor. Hal ini mengakibatkan krisis keuangan ini berimbas terhadap sektor riil di Amerika dan mempengaruhi negara-negara lain yang bergantung kepada ekspor ke Amerika, sehingga dampak dari krisis di Amerika pun berimbas terhadap negara-negara lain dan menyebabkan Krisis Keuangan Global.

Akibat naiknya harga-harga serta ketidakpastian ekonomi, daya beli masyarakat turun secara tajam yang berimbas pada turunnya penjualan di sektor non-primer seperti kendaraan bermotor. Hal ini terlihat ketika pada bulan November 2008, General Motors, perusahaan otomotif terbesar kedua di dunia yang telah berdiri sejak tahun 1908, menyatakan adanya kemungkinan untuk menutup usahanya akibat penurunan tajam di bidang penjualan serta berkurangnya cadangan kas yang mencerminkan besarnya pengaruh krisis tersebut pada industri otomotif di Amerika.

Krisis ini pun berpengaruh terhadap fluktuasi harga minyak dunia. Harga minyak dunia dari tahun ke tahun cenderung naik karena komoditi ini merupakan komoditi yang persediaannya terus menipis, sedangkan permintaan akan komoditi ini selalu naik seiring dengan perkembangan ekonomi dunia. Akibatnya banyak investor yang memilih untuk berinvestasi di komoditi yang dinilai menguntungkan ini. Selain itu, perdagangan minyak bumi masih dikuasai oleh Amerika. Dengan banyaknya investor yang memilih untuk menyimpan minyak bumi sebagai investasi, Amerika juga memanfaatkan hal ini untuk mengendalikan pertumbuhan ekonomi negara-negara pesaing, seperti RRC, Jepang atau Rusia. Negara-negara ini memiliki pertumbuhan ekonomi yang sangat tinggi dan memiliki potensi untuk menjadi negara adikuasa, yang tentu akan sangat dihindari oleh Amerika. Namun setelah terjadinya krisis yang memuncak di tahun 2008, terjadi penarikkan dana investor (unwinding) secara besar-besaran, yang tadinya digunakan untuk berinvestasi di minyak bumi, untuk dipergunakan sebagai penopang kondisi ekonomi yang semakin terpuruk akibat krisis. Karena meningkatnya cadangan minyak di pasar, serta menurunnya permintaan atas minyak akibat kelesuan perdagangan setelah krisis, harga minyak dunia menurun secara drastis.

Di Indonesia, dampak dari krisis keuangan pun juga dapat dirasakan terutama dengan adanya kenaikan kurs valuta asing yang mengakibatkan jatuhnya mata uang rupiah serta sentimen negatif pasar bahwa permintaan energi akan turun akibat krisis keuangan global yang mengakibatkan 
turunnya harga bahan bakar minyak. Harga bahan minyak di dalam negeri juga menurun akibat turunnya harga minyak dunia.

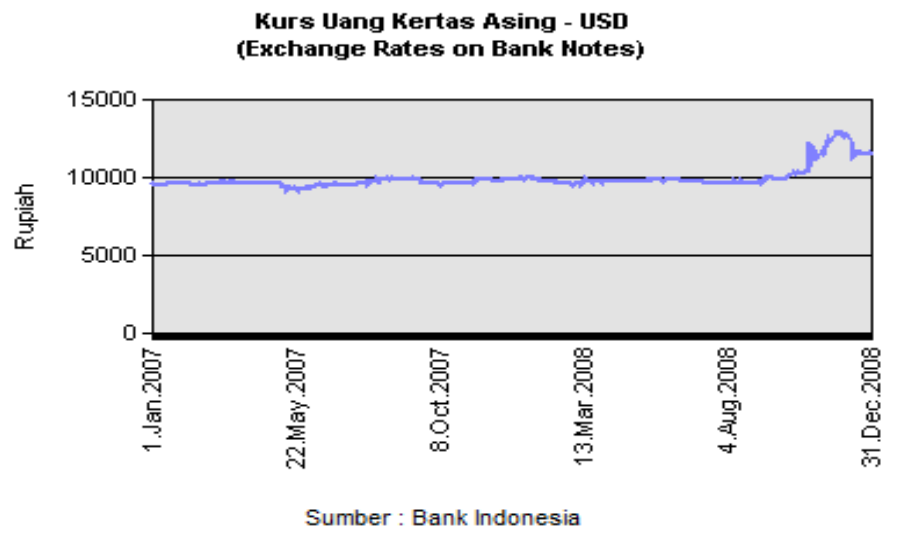

Tabel 1 Fluktuasi Nilai Tukar US Dolar Terhadap Rupiah

(Periode 1 Januari 2007 - 31 Desember 2008)

Industri otomotif di tanah air sangat rentan terhadap perubahan di Fluktuasi kurs valuta asing serta harga bahan bakar minyak (BBM) yang terjadi akibat krisis ini. Pengaruhnya antara lain: (1) naiknya kurs valuta asing berakibat pada naiknya harga komponen industri otomotif yang mayoritas harus diimpor dari negara lain; (2) naiknya kurs valuta asing berakibat naiknya harga-harga dan turunnya daya beli masyarakat; (3) turunnya daya beli masyarakat yang akan mempengaruhi penjualan. Maka dapat disimpulkan, perubahan di kedua variabel tersebut akan sangat berpengaruh terhadap kinerja keuangan di industri otomotif, secara khusus terhadap PT Astra Internasional Tbk yang sebagian komponen produknya didapatkan dari luar negri.

PT Astra Internasional Tbk dianggap dapat mewakili industri otomotif di Indonesia, karena dapat dikatakan perusahaan ini merupakan perusahaan otomotif terbesar di Indonesia, yang merupakan Agen Tunggal Pemegang Merk untuk Toyota, Daihatsu, Isuzu, Nissan Truk Diesel, BMW, Peugeot serta Motor Honda. Perusahaan ini juga telah berdiri sejak tahun 1957 dan telah go-public sejak 1990. Selain itu, perusahaan ini juga terbukti dapat bertahan selama krisis di tahun 1998, bahkan di tahun 1999 masih dapat mencetak keuntungan mencapai 800 miliar rupiah. Perusahaan ini juga telah diakui sebagai perusahaan Indonesia yang paling bergengsi oleh The Wall Street Journal (Jumat-Minggu, 911 Mei 2008). Karena itu, penulis menganalisa kondisi keuangan PT. Astra Internasional Tbk dalam penelitian berjudul Analisis Pengaruh Fluktuasi Kurs Valuta Asing dan Kebijakan Harga Bahan Bakar Minyak dalam Periode 2000-2008 Terhadap Kinerja PT Astra Internasional di Indonesia.

\section{Tujuan dan Manfaat}

Mengetahui kondisi keuangan PT Astra Internasional Tbk akibat fluktuasi kurs valuta asing serta kebijakan harga BBM di tahun 2000-2008. Manfaat bagi pembaca, yaitu: (1) sebagai informasi kondisi keuangan PT Astra Internasional Tbk. di Indonesia serta masukan dalam pertimbangan investasi; (2) sebagai gambaran atas kemampuan PT. Astra Internasional Tbk. di Indonesia dalam menghadapi krisis keuangan global; (3) sebagai sarana untuk menunjukkan bahwa pengukuran kinerja perusahaan dapat menggunakan pendekatan berbasis akuntansi. 


\section{METODE PENELITIAN}

Penelitian dilakukan dengan cara penelitian perpustakaan serta analisis laporan keuangan dan penjualan PT. Astra Internasional Tbk tahun 2000-2008.

\section{Laporan Keuangan}

\section{Arti dan Pentingnya Laporan Keuangan}

Laporan keuangan dapat diartikan sebagai catatan informasi keuangan suatu perusahaan dalam periode akuntansi tertentu yang menggambarkan kinerja perusahaan. Menurut Munawir (2004) Laporan Keuangan adalah merupakan "hasil akhir dari proses akuntansi yang dapat digunakan sebagai alat untuk mengkomunikasikan posisi keuangan suatu perusahaan kepada pihak-pihak yang berkepentingan dengan data ataupun aktivitas perusahaan tersebut.Proses Akuntansi tersebut mencakup pengumpulan serta pengolahan berbagai data keuangan perusahaan, yang dilakukan melalui pengukuran, pencatatan, penggolongan, dan pengikhtisaran transaksi-transaksi yang bersifat keuangan sedemikian rupa sehingga hanya informasi yang relevan dan saling berhubungan, yang mampu memberikan gambaran yang layak tentang posisi keuangan suatu perusahaan dalam suatu periode, yang disajikan dalam bentuk laporan keuangan. Sedangkan pihak-pihak yang berkepentingan terhadap posisi keuangan maupun kinerja suatu perusahaan antara lain: para pemilik perusahaan, manajemen perusahaan, para kreditur, bank, para investor, pemerintah, serta karyawan perusahaan.

Menurut Standar Akuntansi Keuangan Indonesia dalam Ikatan Akuntansi Indonesia (2007), laporan keuangan bertujuan untuk: (1) menyediakan informasi yang menyangkut posisi keuangan, kinerja, serta perubahan posisi keuangan suatu perusahaan yang bermanfaat bagi sejumlah besar pengguna dalam pengambilan keputusan ekonomi; (2) menunjukkan apa yang telah dilakukan manajemen (stewardship), atau pertanggung jawaban manajemen atas sumber daya yang dipercayakan kepadanya. Sedangkan menurut Helfert (2003), hal-hal yang ingin diketahui oleh pengguna laporan keuangan antara lain: apakah sumber daya perusahaan telah digunakan secara efektif; apakah keuntungan perusahaan telah mencapai target; apakah keputusan investasi telah dilakukan secara tepat.

Informasi yang menyangkut posisi keuangan, kinerja serta perubahan posisi keuangan sangat diperlukan oleh pengguna laporan keuangan untuk melakukan evaluasi atas kemampuan perusahaan dalam menghasilkan keuntungan serta untuk menilai perubahan potensial sumber daya ekonomi perusahaan dimasa depan. Sehingga pengguna laporan keuangan dapat memprediksi kemampuan perusahaan dalam menghasilkan kas dan setara kas dan efektivitas perusahaan dalam menggunakan sumber dayanya. Sehingga dapat disimpulkan bahwa laporan keuangan bertujuan untuk memberikan informasi kepada pengguna tentang kondisi perusahaan serta sebagai alat pertanggung jawaban manajemen mengenai penggunaan sumber daya perusahaan yang dipercayakan kepada mereka.

Namun untuk tujuan analisis yang lebih mendalam, tidak cukup hanya didasarkan pada laporan keuangan saja, melainkan juga harus memperhatikan keterangan-keterangan lain yang tercantum dalam laporan tahunan perusahaan, seperti: kondisi dan faktor ekonomi yang mempengaruhi, luasnya produksi, kebijaksanaan perusahaan dan sebagainya (Jumingan, 2006). Karena laporan keuangan tidak dapat menyediakan semua informasi yang mungkin dibutuhkan pengguna dalam pengambilan keputusan ekonomi karena laporan keuangan memiliki keterbatasanketerbatasan.

Menurut Munawir (2004) keterbatasan laporan keuangan antara lain: (1) laporan keuangan pada dasarnya merupakan laporan interim, yaitu laporan yang dibuat antara waktu tertentu yang bersifat sementara, dan bukan merupakan laporan yang final; (2) laporan keuangan menunjukkan 
angka dalam satuan moneter yang kelihatannya bersifat pasti dan tepat, namun sebenarnya penyusunannya dilakukan dengan standar nilai yang mungkin berbeda atau berbeda-beda. Laporan keuangan dibuat berdasarkan konsep going concern sehingga aktiva tetap dinilai berdasarkan nilai historis atau harga perolehannya. Karena itu angka yang tercantum dalam laporan keuangan hanya merupakan nilai buku yang belum tentu sama dengan harga pasar sekarang maupun nilai jualnya; (3) laporan keuangan disusun berdasarkan hasil pencatatan transaksi keuangan atau nilai rupiah di masa lalu, dimana daya beli uang akan semakin menurun dibandingkan dengan tahun-tahun sebelumnya, sehingga kenaikan volume penjualan yang dinyatakan dalam rupiah belum tentu menunjukkan unit yang dijual semakin besar; (4) laporan keuangan tidak mencerminkan berbagai faktor yang dapat mempengaruhi posisi atau keadaan keuangan karena faktor-faktor tersebut tidak dapat dinyatakan dengan satuan uang

\section{Unsur-Unsur Laporan Keuangan}

Dalam Standar Akuntansi Keuangan Indonesia, laporan keuangan yang lengkap terdiri dari Neraca, Laporan Perhitungan Rugi-Laba, Laporan Perubahan Ekuitas, Laporan Arus Kas, serta Catatan Atas Laporan Keuangan (Ikatan Akuntan Indonesia, 2007). Menurut Helfert (2003), neraca merupakan laporan yang menggambarkan kategori dan jumlah aset, kewajiban serta modal perusahaan pada tanggal tertentu. Sedangkan Munawir (2004) menggambarkan Neraca sebagai laporan yang sistematis tentang aset, kewajiban serta modal dari suatu perusahaan pada suatu saat tertentu, sehingga tujuan neraca adalah untuk menunjukkan posisi keuangan suatu perusahaan pada suatu tanggal tertentu.

Munawir (2004) membagi neraca menjadi tiga bagian utama yaitu aset, kewajiban dan ekuitas. Aset, merupakan sumber daya yang dikuasai perusahaan sebagai akibat dari peristiwa masa lalu dan dari mana manfaat ekonomi di masa depan diharapkan diperoleh perusahaan (Ikatan Akuntan Indonesia, 2007). Aset mencakup kekayaan perusahaan, baik berwujud maupun tidak berwujud, biaya dibayar di muka, serta penerimaan di masa yang akan datang (piutang). Aset terdiri dari aset lancar dan aset tidak lancar.

Aset lancar adalah uang tunai serta aset lainnya yang dengan mudah dicairkan atau ditukarkan menjadi uang tunai, seperti piutang usaha, piutang wesel, investasi jangka pendek, serta biaya dibayar di muka. Suatu aset akan dikategorikan sebagai aset lancar jika diperkirakan akan dipergunakan atau dijual dalam jangka waktu siklus operasi normal perusahaan, yaitu dalam waktu kurang dari 12 bulan dari tanggal neraca. Aset tidak lancar adalah aset yang memiliki umur kegunaan jangka panjang dan tidak akan habis dalam satu kali perputaran operasi perusahaan. Contohnya antara lain : Investasi Jangka Panjang (saham, obligasi, dan aset tetap yang tidak digunakan untuk kepentingan operasional perusahaan), Aset tetap (tanah, bangunan, kendaraan, inventaris, mesin), aset tidak berwujud (hak cipta, goodwill), serta beban yang ditangguhkan.

Kewajiban, merupakan utang perusahaan di masa kini terhadap pihak lain yang timbul dari peristiwa di masa lalu, yang penyelesaiannya akan mengakibatkan arus keluar dari sumber daya perusahaan yang mengandung manfaat ekonomi. Sedangkan Munawir (2004) mendefinisikan kewajiban sebagai sumber dana atau modal perusahaan yang berasal dari pihak lain. Kewajiban dapat dibedakan menjadi Kewajiban lancar (Kewajiban jangka pendek) dan Kewajiban jangka panjang. Kewajiban lancar yaitu utang perusahaan yang pelunasannya akan dilakukan dalam jangka waktu satu tahun setelah tanggal neraca (contohnya : hutang dagang, hutang pajak, biaya yang masih harus dibayar, hutang jangka panjang yang akan segera jatuh tempo, serta penghasilan diterima dimuka). Sedangkan Kewajiban jangka panjang merupakan utang perusahaan yang waktu jatuh temponya lebih dari satu tahun setelah tanggal neraca, seperti : hutang obligasi, hutang hipotik, serta pinjaman jangka panjang yang lain. 
Ekuitas merupakan hak residual pemilik perusahaan atas aset perusahaan setelah dikurangi semua kewajiban. Yang termasuk dalam kategori ekuitas antara lain saham biasa, saham preferen, ataupun setoran dari pemilik.

Laporan Perhitungan Laba-rugi merupakan laporan sistematis tentang penghasilan, biaya, laba-rugi yang diperoleh oleh perusahaan selama periode tertentu, yang menggambarkan hasil-hasil yang telah dicapai oleh perusahaan serta biaya yang digunakan untuk mencapai hasil tersebut. Menurut Helfert (2003), laporan ini mencerminkan pengaruh keputusan operasi manajemen terhadap kinerja perusahaan. Dalam laporan laba-rugi, terdapat bagian yang menunjukkan: (1) penghasilan yang diperoleh dari usaha pokok perusahaan diikuti dengan harga pokok dari usaha tersebut; (2) biayabiaya operasional yang terdiri dari biaya penjualan dan biaya administrasi dan umum; (3) hasil-hasil yang diperoleh di luar operasi pokok perusahaan, yang diikuti dengan biaya-biaya yang terjadi di luar usaha pokok perusahaan.

Laporan Perubahan Ekuitas menunjukkan sumber dan perubahan yang terjadi pada ekuitas perusahaan selama satu periode akuntansi. Perubahan yang terjadi diakibatkan oleh adanya pengambilan pribadi, diperolehnya laba, dideritanya kerugian atau adanya setoran pribadi. Laporan perubahan ekuitas berisi antara lain: (1) modal awal yaitu modal awal tahun; (2) tambahan investasi pemilik, yaitu setoran modal dari pemilik selama satu periode akuntansi; (3) laba atau rugi adalah hasil bersih perusahaan selama satu periode akuntansi; (4) pengambilan pribadi adalah pengambilan uang untuk keperluan pribadi pemilik perusahaan selama satu periode akuntansi; (5) modal akhir adalah modal yang terdapat pada akhir tahun.

Laporan Arus Kas menyajikan informasi arus kas selama periode tertentu dan diklasifikasikan menurut aktivitas operasi, investasi, dan pendanaan. Laporan ini diperlukan untuk mengetahui kemampuan perusahaan yang sebenarnya dalam memenuhi kewajiban-kewajibannya. Arus Kas yang berasal dari aktivitas operasi, merupakan indikator yang menentukan apakah operasi perusahaan dapat menghasilkan arus kas yang cukup untuk melunasi pinjaman, memelihara kemampuan operasi perusahaan, membayar dividen, dan melakukan investasi baru tanpa mengandalkan sumber pendanaan dari luar. Arus kas dari aktivitas ini terutama diperoleh dari transaksi dan peristiwa lain yang merupakan sumber utama pendapatan perusahaan yang mempengaruhi penetapan laba atau rugi bersih, seperti: penerimaan kas dari penjualan barang atau jasa; penerimaan kas dari royalti, komisi, dan pendapatan lain; pembayaran kepada pemasok barang dan jasa; atau pembayaran gaji atau upah kepada pegawai.

Arus Kas yang berasal dari aktivitas investasi, mencerminkan penerimaan dan pengeluaran kas yang berhubungan dengan pendapatan atau arus kas di masa depan. Beberapa contoh arus kas dari aktivitas ini antara lain: pembayaran kas untuk membeli aset tetap, aset tidak berwujud, dan aset jangka panjang lain; penerimaan kas dari penjualan tanah, bangunan, atau peralatan; perolehan saham atau instrumen keuangan perusahaan lain.

Arus Kas yang berasal dari aktivitas pendanaan, berguna untuk memprediksi klaim terhadap arus kas di masa depan oleh para pemasok modal perusahaan. Beberapa contoh arus kas yang berasal dari aktivitas pendanaan adalah: penerimaan kas dari emisi saham atau instrumen modal lainnya; pembayaran kas kepada para pemegang saham untuk menarik atau menebus saham perusahaan; penerimaan kas dari emisi obligasi, pinjaman, wesel, hipotek, dan pinjaman lainnya; pelunasan pinjaman; pembayaran kas oleh penyewa (lessee) untuk mengurangi saldo kewajiban yang berkaitan dengan sewa pembiayaan (financial lease).

Catatan Atas Laporan Keuangan meliputi penjelasan naratif yang menggambarkan perubahanperubahan yang terjadi yang tidak dapat dijelaskan di keempat laporan lainnya. Antara lain mengungkapkan: (1) informasi tentang dasar penyusunan laporan keuangan dan kebijakan akuntansi yang dipilih dan diterapkan terhadap peristiwa dan transaksi yang penting; (2) informasi yang 
diwajibkan dalam PSAK ataupun informasi tambahan yang tidak disajikan di neraca, laporan laba rugi, laporan arus kas serta laporan perubahan ekuitas, namun diperlukan dalam penyajian laporan keuangan secara wajar.

\section{Analisa Laporan Keuangan}

\section{Arti dan Pentingnya Analisa Laporan Keuangan}

Analisa laporan keuangan merupakan suatu proses untuk mempelajari serta menginterpretasikan laporan keuangan, sehingga dapat diperoleh pengertian dan pemahaman yang dapat dimanfaatkan oleh penggunanya.Analisa laporan keuangan menjadi penting karena, meskipun laporan keuangan merupakan alat yang sangat penting untuk memperoleh informasi sehubungan dengan posisi keuangan dan hasil-hasil yang telah dicapai oleh perusahaan bersangkutan, seperti yang disebutkan oleh Higgins (2000): accounting translates a company's diverse activities into a set of objective numbers that provide information about firm's performance, problems, and prospects. Finance involves the interpretation of these accounting numbers for assessing performance and planning future actions.

Munawir (2004) menambahkan bahwa data keuangan tersebut akan lebih berarti bagi pihakpihak yang berkepentingan apabila data tersebut diperbandingkan untuk dua periode atau lebih, dan dianalisis lebih lanjut sehingga dapat diperoleh data yang akan dapat mendukung keputusan yang akan diambil. Selain itu, Wild, Bernstein \& Subramanyan (2004) juga menyebutkan bahwa analisis laporan keuangan dapat mengurangi penggunaan firasat, perkiraan, dan intuisi dalam pengambilan keputusan bisnis, ketidakpastian dalam analisis bisnis dapat dikurangi. Bagi pihak manajemen, analisa laporan keuangan penting untuk dapat mengevaluasi kinerja perusahaan, kompensasi dan pengembangan karier. Bagi pemegang saham, analisa laporan keuangan penting untuk mengetahui kinerja perusahaan, pendapatan dan kenyamanan investasi. Bagi kreditor analisa laporan keuangan digunakan untuk mengetahui kemampuan perusahaan dalam melunasi hutang serta bunganya. Bagi pemerintah analisa laporan keuangan digunakan demi kepentingan pajak serta persetujuan untuk go publik. Menurut Munawir (2004) Tehnik analisa laporan keuangan yang dapat digunakan untuk mengukur kinerja perusahaan antara lain: (1) Analisa Perbandingan Laporan Keuangan, yaitu metode analisa dengan membandingkan laporan keuangan untuk dua periode atau lebih, dengan menunjukkan: data absolut atau jumlah dalam rupiah, kenaikan atau penurunan dalam jumlah rupiah, kenaikan atau penurunan dalam presentase atau persentase total; (2) tren keuangan perusahaan yang dinyatakan dalam presentase (trend precentage analysis), yaitu metode analisa dengan mengukur kecenderungan kondisi keuangan perusahaan; (3) laporan dengan presentase per komponen atau common size statement, yaitu suatu metode analisis untuk mengetahui persentase investasi pada masing-masing aktiva terhadap total aktivanya, juga untuk mengetahui struktur permodalannya dan komposisi pembiayaan yang terjadi jika dihubungkan dengan jumlah penjualannya; (4) Analisa Sumber dan penggunaan modal kerja, yaitu suatu analisa untuk mengetahui sumber-sumber penggunaan modal kerja dan penggunaannya serta sebab-sebab perubahan modal kerja dalam periode tertentu; (5) Analisa Sumber dan penggunaan kas, yaitu suatu analisa untuk mengetahui sumber-sumber penggunaan kas dan penggunaannya serta sebabsebab perubahan jumlah kas dalam periode tertentu; (6) Analisa Rasio, yaitu metode analisa untuk mengetahui hubungan dari pos-pos tertentu dalam laporan keuangan; (7) Analisis perubahan laba kotor (gross profit analysis), yaitu suatu analisis untuk mengetahui sebab-sebab perubahan laba kotor suatu perusahaan dari periode ke periode yang lain atau perubahan laba kotor suatu periode dengan laba yang dibudgetkan untuk periode tersebut; (8) Analisis break even, yaitu suatu analisis untuk menentukan tingkat penjualan yang baru harus dicapai oleh suatu perusahaan agar perusahaan tersebut tidak mengalami kerugian, tetapi juga belum memperoleh keuntungan. Dengan analisis break-event ini juga akan diketahui berbagai tingkat keuntungan atau kerugian untuk berbagai tingkat penjualan. 


\section{HASIL DAN PEMBAHASAN}

\section{Sejarah Perusahaan}

Astra Internasional didirikan sejak tanggal 20 Februari 1957 sebagai perusahaan dagang kecil oleh Tjia Kian Tie dan William Soerjadjaja. Seiring dengan waktu, perusahaan ini berkembang menjadi produser dan distributor otomotif serta komponennya yang terbesar di Indonesia melalui partnering dengan perusahaan Jepang seperti Toyota, Daihatsu dan Isuzu. Astra mengembangkan bisnisnya bukan hanya di bidang otomotif tetapi juga dibidang jasa keuangan, alat-alat berat, agro industri dan juga teknologi informasi. Namun, perusahaan ini tetap memusatkan fokusnya pada divisi terbesarnya yaitu produksi dan distribusi otomotif dan komponennya, yang menyumbang hampir 83\% dari total pendapatan PT Astra Internasional setiap tahunnya.

Perusahaan dengan nilai market capital 110,5 triliun rupiah ini telah tercatat di Bursa Efek Jakarta dan Surabaya sejak 4 April 1990 dan sekarang mayoritas kepemilikan sahamnya dimiliki oleh Jardine Cycle \& Carriage Singapura yang merupakan perusahaan besar yang membawahi merk Kia, Mercedes-Benz, dan Mitsubishi di Singapura. Di akhir tahun 2007, diperkirakan Astra Group telah memiliki jumlah karyawan sebesar 118.700 orang yang tersebar di 130 anak perusahaan.

\section{Kantor Pusat}

Jl. Gaya Motor Raya No. 8

Sunter II - Jakarta Utara

Jakarta 14330 - Indonesia

No. Telp: (62-21) 6522555

Fax: (62-21) 6512058

Email: purel@ai.astra.co.id

Hasil penelitian yang didapatkan oleh penulis, berdasarkan analisis terhadap laporan keuangan PT Astra Internasional Tbk untuk periode 2000-2008, mengevaluasi kinerja PT Astra Internasional berdasarkan Analisa Pengaruh Fluktuasi Kurs Valuta Asing dan Bahan Bakar Minyak Terhadap Kinerja PT. Astra Internasional.Hasil penghitungan aspek-aspek keuangan PT Astra Internasional menunjukkan bahwa pada tahun 2005 perusahaan mengalami penurunan kinerja, yang dapat dilihat dari penurunan tingkat pendapatan sebesar $10 \%$, yang juga berakibat pada turunnya tingkat laba, likuiditas PT Astra Internasional juga mengalami penurunan sebesar 30\% di tahun 2005, rasio-rasio aktivitas pun menunjukkan adanya penurunan di tahun 2005. Hal ini juga terjadi secara tidak signifikan di tahun 2008, dimana terjadi penurunan tingkat pertumbuhan laba dibandingkan dengan tahun sebelumnya.

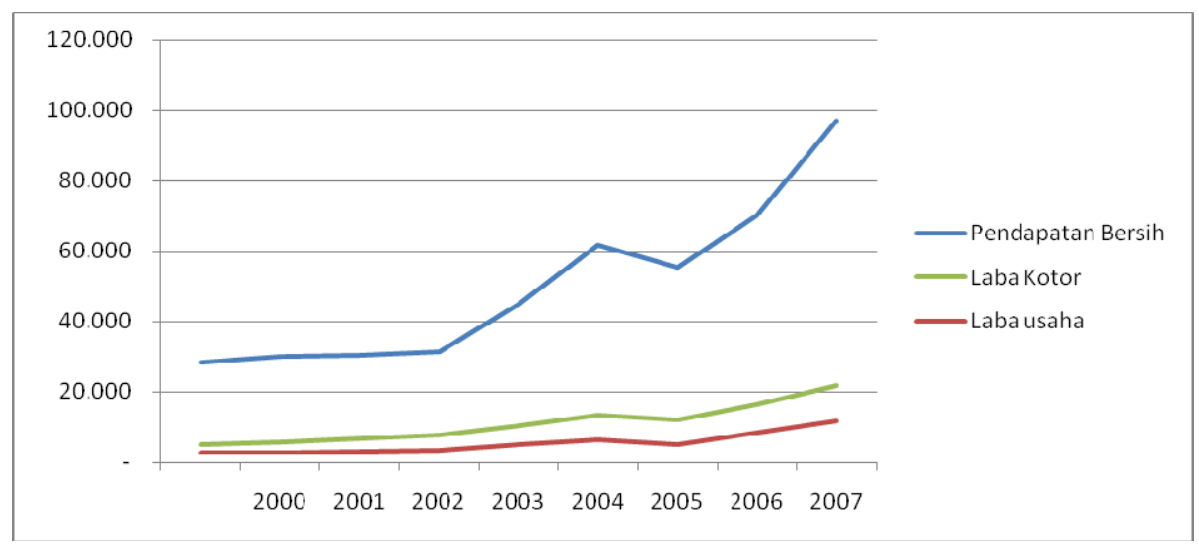

Gambar 1 Tingkat Pendapatan PT Astra Internasional Tbk 
Di tahun 2005 terjadi dua kali kenaikan harga BBM, yaitu di bulan Maret dan bulan Oktober. Dan di bulan Oktober 2005 merupakan titik tertinggi kurs valuta asing. Sedangkan di tahun 2008, terjadi kenaikan harga BBM serta di bulan Oktober, nilai tukar rupiah mengalami titik terlemah sepanjang periode tahun 2000-2008. Namun di bulan Desember, harga BBM mengalami perbaikan serta menguatnya nilai tukar rupiah. Hal ini berpengaruh pada beban pokok pendapatan PT Astra Internasional. Ditahun 2005 beban pokok pendapatan PT Astra Internasional, yang antara lain mencakup biaya impor bahan baku, suku cadang, serta kendaraan bermotor yang belum dirakit, mengalami peningkatan sebesar 40\%. hal ini kembali terjadi di tahun 2008 dimana beban pokok pendapatan PT Astra Internasional mengalami peningkatan sebesar 17\%. Di bidang pendapatan, penjualan PT Astra Internasional pun mengalami penurunan sebesar 10\% di tahun 2006 yang disebabkan oleh turunnya tingkat penjualan kendaraan bermotor domestik sebesar 40,3\% di tahun 2006 akibat lemahnya permintaan pasar sejak kenaikan harga bahan bakar minyak di tahun 2005.

Sehingga dapat disimpulkan penurunan kinerja PT Astra Internasional secara signifikan di tahun 2005 serta secara tidak signifikan di tahun 2008 secara tidak langsung diakibatkan oleh kenaikan tingkat suku bunga dan valuta asing serta kenaikkan harga bahan bakar minyak yang mengakibatkan lemahnya permintaan pasar akibat menurunnya daya beli masyarakat, dan meningkatnya beban pokok pendapatan serta biaya operasional perusahaan.

\section{PENUTUP}

Berikut ini adalah kesimpulan dan saran dari pembahasan atas penilaian kinerja PT Astra Internasional, yang merupakan salah satu kelompok bisnis terbesar di Indonesia yang terutama bergerak di bidang otomotif, namun juga memiliki anak-anak perusahaan di bidang jasa keuangan, agribisnis, alat-alat berat, teknologi informasi dan infrastruktur. Secara umum, kinerja PT Astra Internasional mengalami peningkatan sejak tahun 2000, namun di tahun 2005 sedikit menurun. Penurunan kinerja juga terjadi di tahun 2008 meski tidak signifikan seperti di tahun 2005.

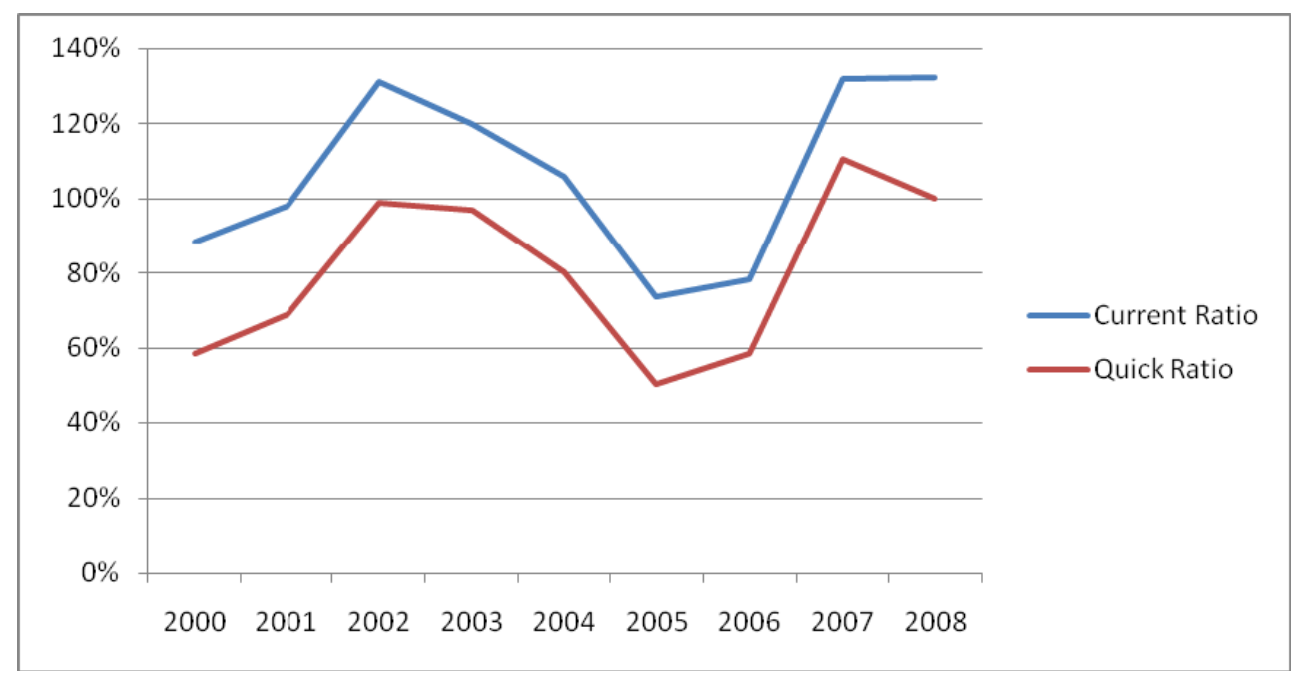

Gambar 2 Rasio-rasio likuiditas PT Astra Internasional Tbk 


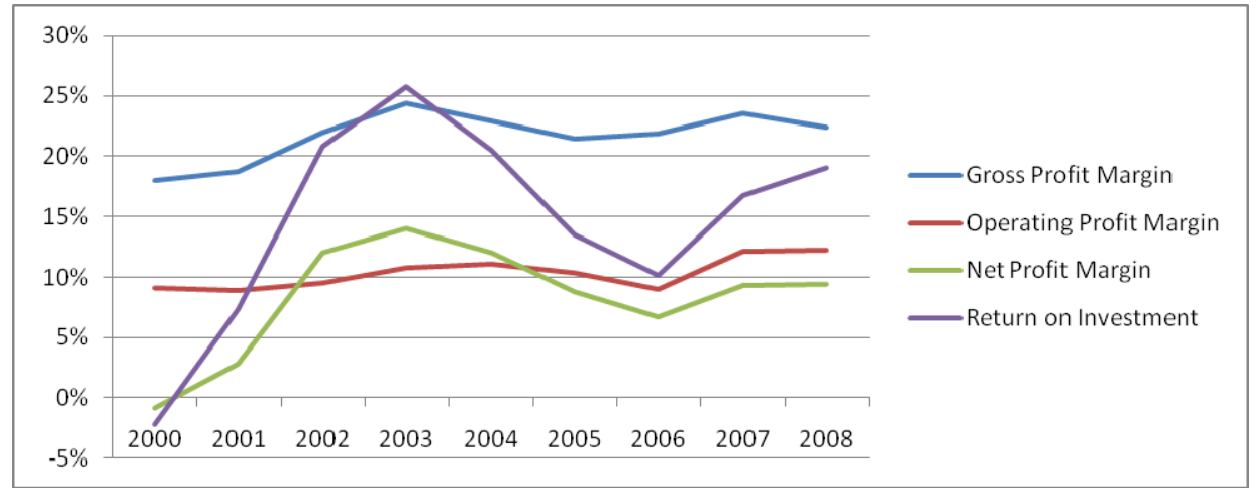

Gambar 3 Rasio-rasio profitabilitas PT Astra Internasional Tbk

Penurunan kinerja tersebut secara langsung diakibatkan oleh: turunnya tingkat pendapatan, terutama di penjualan kendaraan bermotor dan suku cadangnya di tahun-tahun tersebut dan naiknya biaya pokok pendapatan, akibat naiknya biaya impor serta biaya pengiriman. Turunnya tingkat pendapatan di tahun 2005 dan 2008 disebabkan oleh menurunnya tingkat penjualan kendaraan bermotor domestik di tahun-tahun tersebut akibat lemahnya permintaan pasar sejak kenaikan harga bahan bakar minyak di tahun 2005. Naiknya biaya pokok pendapatan di tahun 2005 dan 2008 antara lain disebabkan oleh kenaikan kurs dolar secara signifikan di tahun-tahun tersebut, serta naiknya harga bahan bakar minyak di tahun 2005 dan 2008. Fluktuasi kurs valuta asing serta kebijakan harga bahan bakar minyak mempengaruhi kinerja PT. Astra Internasional secara tidak langsung.

\section{Saran}

Berdasarkan kesimpulan-kesimpulan di atas, penulis membuat saran, yaitu: (1) likuiditas, untuk menghindari penurunan rasio likuiditas di masa yang akan datang, sebaiknya perusahaan menghindari untuk menambah pinjaman jangka pendeknya ketika terjadi kenaikan kurs valuta asing. Dan sebaiknya perusahaan mempercepat penagihan piutang untuk mempercepat konversi menjadi kas, serta mengurangi pengeluaran yang tidak perlu sehingga jumlah kas tetap terjaga; (2) aktivitas, untuk memperbaiki rasio aktivitas, perusahaan perlu meninjau kembali kebijakan kredit serta meningkatkan kinerja bagian penagihan sehingga diharapkan mempercepat konversi piutang menjadi kas; (3) solvabilitas, sebagian besar aset perusahaan masih dibiayai dengan hutang. Perusahaan harus menambah jumlah ekuitasnya sehingga perusahaan tidak perlu membayar bunga hutang yang besar, misalnya dengan melakukan penerbitan dan penjualan saham baru, sehingga jumlah ekuitasnya meningkat dan mampu membiayai kegiatan operasional perusahaan; (4) profitabilitas, untuk mengatasi kenaikan harga bahan pokok akibat naiknya kurs valuta asing serta kenaikan harga bahan bakar minyak, perusahaan perlu lebih mengefektifkan biaya yang dikeluarkan dengan mengurangi biaya-biaya yang tidak perlu, misalnya biaya perjalanan yang tidak mendesak.

\section{DAFTAR PUSTAKA}

Crotty, J. (2008). Structural cause of the global financial crisis: a critical assessment of the 'New Financial Architecture'. Amherst: University of Massachusetts.

Helfert, E. A. (2003). Techniques of financial analysis (11th ed). McGraw-Hill.

Ikatan Akuntan Indonesia. (2007). Standar akuntansi keuangan. Jakarta: Salemba Empat. 
Jumingan. (2006). Analisis laporan keuangan. Jakarta: Bumi Aksara.

Munawir, S. (2004). Analisa laporan keuangan (4th ed.). Yogyakarta: Liberty.

Wild, J. J., Bernstein, L. A., \& Subramanyan, K. R. (2004). Financial statement analysis (7th ed.). New York: McGraw-Hill. 